1 Population genomics data supports introgression between western

4 Sofia L. Mendes ${ }^{1}$, Maria M. Coelho ${ }^{1 *}$, Vitor C. Sousa ${ }^{1 *}$

$5{ }^{1} \mathrm{cE} 3 \mathrm{c}-$ Centre for Ecology, Evolution and Environmental Changes,

6 Faculdade de Ciências da Universidade de Lisboa, Lisbon, Portugal

7 *These authors contributed equally to this work

$8 \quad \&$ corresponding author: vmsousa@fc.ul.pt 
12 In freshwater fish, processes of population divergence and speciation are

13 often linked to the geomorphology of rivers and lakes that isolate

14 populations. However, current geographical isolation does not necessarily

15 imply total absence of gene flow during the divergence process. Here, we

16 focused on four species of the genus Squalius in Portuguese rivers: $S$.

17 carolitertii, S. pyrenaicus, S. aradensis and S. torgalensis. Previous studies

18 based on eight nuclear and mitochondrial markers revealed incongruent

19 patterns, with nuclear loci suggesting that $S$. pyrenaicus was a paraphyletic

20 group since its northern populations were genetically closer to $S$. carolitertii

21 than to its southern populations. For the first time, we successfully applied

22 a genomic approach to the study of the relationship between these species,

23 using a Genotyping by Sequencing (GBS) approach. Our results revealed a

24 species tree with two main lineages: (i) S. carolitertii and S. pyrenaicus; (ii)

25 S. torgalensis and S. aradensis. Regarding S. carolitertii and S. pyrenaicus,

26 we found evidence for past introgression between the two in the northern

27 part of S. pyrenaicus distribution. This introgression reconciles previous

28 mitochondrial and nuclear incongruent results and explains the apparent

29 paraphyly of $S$. pyrenaicus. Our demographic modelling estimates are

30 consistent across models, suggesting that the northern populations of $S$.

31 pyrenaicus received a contribution of approximately $90 \%$ from S. carolitertii

32 and $10 \%$ from southern S. pyrenaicus. This illustrates that even in

33 freshwater species currently allopatric, we are able to detect past gene flow 
bioRxiv preprint doi: https://doi.org/10.1101/585687 this version posted July 20,2019 . The copyright holder for this preprint (which was not certified by peer review) is the author/funder, who has granted bioRxiv a license to display the preprint in perpetuity. It is made available under aCC-BY-NC-ND 4.0 International license.

34 events in present-day genomes, suggesting speciation is more complex

35 than simply allopatric.

36

37 Key-words: Iberian freshwater fish; introgression; speciation; demographic

38 modelling 
41 ultimately originate new species is a major goal of evolutionary biology.

42 Speciation is assumed to occur due to a systematic reduction in gene flow

43 through time until reproductive isolation is achieved and populations

44 maintain phenotypic and genetic distinctiveness (Seehausen et al., 2014).

45 The most accepted hypothesis is that divergence happens in a strictly

46 allopatric scenario in the absence of gene flow, due to barriers (geological,

47 hydrological, etc.). Without gene flow, genetic incompatibilities are

48 expected to accumulate through time which can lead to reproductive

49 isolation (Sousa and Hey, 2013). However, there are now several studies

50 based on phenotypic and genomic data suggesting that past gene flow is

51 common in several species, including in humans (e.g. Green et al., 2010;

52 Dasmahapatra et al., 2012; Lamichhaney et al., 2015; vonHoldt et al.,

53 2016; de Manuel et al., 2016). Nevertheless, despite the growing number of

54 examples of gene flow between species, it is still unclear whether gene flow

55 accompanies the divergence process or if populations first get isolated and

56 then come into contact after a period of time, i.e. a secondary contact

57 (Sousa and Hey, 2013). Thus, to understand the process of speciation it is

58 important to characterize the timing and mode of gene flow. The study of

59 these processes has been revolutionized by the possibility of generating

60 genome-wide data from multiple individuals of closely related species to

61 obtain large numbers of polymorphic genetic markers scattered across the

62 genome, either by reduced representation (e.g. genotyping by sequencing) 
63 or whole genome sequencing (Davey et al., 2011; Andrews et al., 2016).

64 These types of data have been used in the study of speciation and the

65 relationship between species in several taxa, from insects (e.g.

66 Dasmahapatra et al. 2012; Bagley et al. 2017) to mammals (e.g. McManus

67 et al. 2015; Figueiró et al. 2017), including freshwater fish (e.g. Hohenlohe

68 et al. 2010; Meier et al. 2017).

Due to their outstanding diversity and remarkable adaptive

70 radiations, freshwater fish species have been widely used as model

71 systems to study speciation (Seehausen and Wagner, 2014). A variety of

72 scenarios have been described to explain the differentiation of different

73 freshwater fish populations, including transitions from marine to freshwater

74 habitats (e.g. Jones et al. 2012; Terekhanova et al. 2014), adaptation to

75 extreme environments (e.g. Pfenninger et al. 2015), and differentiation

76 along water depth clines (e.g. Barluenga et al. 2006; Gagnaire et al. 2013).

77 Another important factor for speciation in freshwater fish is the

78 geomorphology of rivers and lakes, given that such events are often

79 associated with geological barriers isolating populations (Seehausen and

80 Wagner, 2014). However, this does not mean that currently geographically

81 separated populations have always been isolated since the configuration of

82 river and lake systems can change over geological time. In fact, several

83 studies document both past and ongoing introgression in freshwater fish,

84 both in species that have evolved with and without geographical isolation

85 (Redenbach and Taylor, 2002; Jones et al., 2013; Hohenlohe et al., 2013;

86 Gante et al., 2016). Nonetheless, vicariant events resulting from 
87 geographical barriers imposed by the geomorphology of lakes and rivers

88 remains the most accepted explanation for the abundance of freshwater

89 fish species (Seehausen and Wagner, 2014). One geographical area where

90 isolation and the configuration of the drainage systems are assumed to

91 have fuelled the origin of a multitude of endemic fish species is the lberian

92 Peninsula (Sousa-Santos et al., 2019).

The freshwater fish fauna of the Iberian Peninsula includes several

94 endemic species (Mesquita et al., 2007). Among these, a diverse group are

95 the "chubs" from the genus Squalius Bonaparte, 1837, in which there are

96 currently eight species and a hybrid complex described in the peninsula

97 (Perea et al., 2016). In Portuguese rivers, apart from the hybrid complex,

98 four species can be found: Squalius carolitertii, Squalius pyrenaicus,

99 Squalius torgalensis and Squalius aradensis (Figure 1), distributed along a

100 temperature cline, with increasing temperatures from north to south (Jesus

101 et al., 2017). Two of the species have rather wide distribution ranges:

102 Squalius carolitertii (Doadrio, 1988) is endemic to the northern region of the

103 peninsula and can be found in the northern rivers up to the Mondego basin,

104 while Squalius pyrenaicus (Gunther, 1868) has a more southern distribution

105 range and is considered to be present in the Tagus, Sado, Guadiana and

106 south-eastern basins (Coelho et al., 1995, 1998). On the other hand, the

107 two other species are confined only to small river systems in the

108 southwestern area of the country: Squalius torgalensis (Coelho et al., 1998)

109 is endemic to the Mira river basin and Squalius aradensis (Coelho et al., 
110 1998) is restricted to basins (e.g. Arade) in the extreme southwestern area

111 (Coelho et al., 1998).

112 The relationship between these species has been investigated (e.g.

113 Brito et al. 1997; Sanjur et al. 2003; Mesquita et al. 2007; Waap et al. 2011;

114 Sousa-Santos et al. 2019) and estimates based on fossil calibrations,

115 nuclear and mitochondrial markers date their most recent common

116 ancestor to $\approx 14$ Mya (Perea et al., 2010; Sousa-Santos et al., 2019). S.

117 torgalensis and $S$. aradensis were found to be sister species, forming one

118 clade distinct from the clade of sister species $S$. carolitertii and $S$.

119 pyrenaicus, based on both mitochondrial (mtDNA) and nuclear markers

120 (Brito et al., 1997; Mesquita et al., 2007; Almada and Sousa-Santos, 2010;

121 Waap et al., 2011; Sousa-Santos et al., 2019). However, while the mtDNA

122 trees cluster different populations of S. pyrenaicus from different river

123 basins together (Brito et al., 1997; Mesquita et al., 2007), phylogenetic

124 trees produced concatenating 7 nuclear genes suggest that $S$. pyrenaicus

125 individuals from the Tagus river basin cluster with $S$. carolitertii, instead of

126 clustering with S. pyrenaicus from other river basins further south (e.g.

127 Guadiana, Sado, Almargem), which form a separate clade (Waap et al.,

128 2011; Sousa-Santos et al., 2019).

129 While the previous work provided valuable information to

130 understand the diversity and taxonomy of these species (Coelho et al.,

131 1995; Brito et al., 1997; Mesquita et al., 2005; Henriques et al., 2010), their

132 evolutionary history was mostly investigated based on single mtDNA gene

133 trees and recently complemented with seven nuclear markers (Waap et al., 
134 2011; Sousa-Santos et al., 2019). Investigating the history of species based

135 on single genes can be problematic due to highly stochastic events of

136 genetic drift and mutational processes (Hey and Machado, 2003).

137 Moreover, when species diverged relatively recently, gene trees might not

138 reflect the underlying species tree due to incomplete lineage sorting and/or

139 gene flow (Hey and Machado, 2003). Thus, although seven nuclear genes

140 constitute an improvement over phylogenies based only on mitochondrial

141 DNA, it still provides a limited picture of the genome. Therefore, this work

142 had two major goals: (i) first, to characterize the genome-wide patterns of

143 genetic differentiation and reconstruct the species tree for these four

144 Squalius species in Portuguese river basins; (ii) second, to investigate the

145 possibility of introgression between S. carolitertii and S. pyrenaicus, given

146 the previously reported incongruent results between mtDNA and nuclear

147 markers. To achieve these goals, we successfully obtained genome-wide

148 single nucleotide polymorphisms (SNPs) through a Genotyping by

149 Sequencing (GBS) protocol. 


\section{Sampling and sequencing}

A total of 65 individuals were sampled from 8 different locations, as

154 displayed in Figure 1. For each species, at least one sampling location from

155 a representative drainage system was sampled. For S. carolitertii,

156 individuals were collected from the Mondego basin $(n=10)$. For $S$.

157 pyrenaicus, in the northern part of its distribution individuals were collected

158 from the Ocreza river $(n=10)$ and Canha stream $(n=10)$, both tributaries of

159 the Tagus basin. Specimens were also collected in the Lizandro basin

$160(\mathrm{n}=10)$. From here on, we use "northern $S$. pyrenaicus" to refer to $S$.

161 pyrenaicus from Ocreza, Canha and Lizandro. In the southern part of the

162 distribution, S. pyrenaicus was sampled in the Guadiana $(\mathrm{n}=2)$ and

163 Almargem ( $n=8)$ basins, which we refer to as "southern S. pyrenaicus". For

$164 S$. aradensis, individuals were collected from the Arade $(n=5)$ basin. For $S$.

165 torgalensis individuals were collected in the Mira basin $(n=10)$. Detailed

166 locations with GPS coordinates and fishing licenses from the Portuguese

167 authority for conservation of endangered species [ICNF (Instituto de

168 Conservação da Natureza e das Florestas)] can be found in Table S1.

169 Fish were collected by electrofishing (300V, 4A), and total genomic

170 DNA was extracted from fin clips using a phenol-chloroform protocol

171 adapted from Taggart et al., 1992. DNA was quantified using Qubit® 2.0

172 Fluorometer (Live Technologies). The samples were subjected to a paired- 
173 end Genotyping by Sequencing (GBS) protocol (adapted from Elshire et al.,

174 2011), performed in outsourcing at Beijing Genomics Institute (BGI,

175 www.bgi.com). The DNA samples were sent to the facility mixed with

176 DNAstable Plus (Biomatrica) to preserve DNA at room temperature during

177 shipment. Briefly, upon arrival, DNA was fragmented using the restriction

178 enzyme ApeKI and the fragments were amplified after adaptor ligation

179 (Elshire et al., 2011). The resulting library was sequenced using Illumina

180 Hiseq2000.

\section{Obtention of a high-quality SNP dataset}

First, the quality of the sequences of each individual was assessed

184 using FastQC (https://www.bioinformatics.babraham.ac.uk/projects/fastqc/).

185 To compile the information from all individual reports, we used MultiQC

186 (Ewels et al., 2016) to merge and summarize the individual FastQC reports.

187 Second, we used the program process_radtags from Stacks version 2.2

188 (Catchen et al., 2013; Rochette et al., 2019) to trim all reads to 82 base

189 pairs and discard reads with low quality scores, using the default settings

190 for the window size $(0.15 x$ the length of the read) and the base quality

191 threshold (10 in Phred score). Given the absence of a reference genome

192 for any of the species in this study, we built a reference catalog of all loci

193 using a denovo assembly approach on Stacks version 2.2 (Catchen et al.,

194 2013; Rochette et al., 2019). To determine the best parameters for the

195 construction of the catalog, we followed the approach recommended by 
196 Paris et al. 2017 (Figure S1). We decided to allow a maximum of 2

197 differences between sequences within the same individual $(M=2)$ and a

198 maximum of 4 differences between sequences from different individuals

$199(\mathrm{n}=4)$ for them to be considered the same locus on the catalog. We also

200 required a minimum depth of coverage of $4 x$ for every locus on the catalog

$201(m=4)$. After building the catalog, given the possibility that forward and

202 reverse sequences of the same fragment were treated as different loci,

203 similar reads within the catalog were clustered using CD-HIT version 4.7 ( $\mathrm{Li}$

204 and Godzik, 2006; Fu et al., 2012). We used CD-HIT-EST from the CD-HIT

205 package with a word length of 6 and a sequence identity threshold of 0.85 .

206 Once we clustered similar reads within the catalog, this was treated

207 as a reference and the reads from each individual were aligned against it

208 using BWA-MEM from BWA version 0.7.17-r1188 (Li, 2013) with default

209 parameters. The output alignments of BWA were sorted and unmapped

210 reads were removed using Samtools version 1.8 (Li and Durbin, 2009). To

211 call genotypes for each individual at each site and identify SNPs we used

212 the method implemented on Freebayes v1.2.0 (Garrison and Marth, 2012).

213 We applied further filters to keep only SNPs present in all sampling sites in

214 at least $50 \%$ of the individuals using VCFtools version 0.1 .15 (Danecek et

215 al., 2011).

216 To discard sites and genotypes that are more likely to be the result

217 of sequencing or mapping errors, we applied filters on the minor allele

218 frequency (MAF $\geq 0.01$ ) and on the depth of coverage, keeping only

219 genotypes with a depth of coverage (DP) between $1 / 4$ to 4 times the 
220 individual median DP, after assessing the effect of different filtering options

221 (Tables S2 and S3). The different filters were applied using a combination

222 of options from VCFtools version 0.1.15 (Danecek et al., 2011) and

223 BCFtools version 1.6 (Li et al., 2009). Finally, individuals with more than

$22450 \%$ missing data were removed from the dataset.

\section{Characterization of the global patterns of genetic differentiation}

To quantify the levels of differentiation between sampling locations, we calculated the pairwise $\mathrm{F}_{\mathrm{ST}}$ using the Hudson estimator (Hudson et al.,

229 1992). Given that the sampling locations may not correspond to

230 populations, we investigated fine population structure with individual-based

231 methods. To understand how individuals cluster, we conducted a principal

232 component analysis (PCA). The number of significant principal components

233 was determined with the Tracy-Widom test (Patterson et al., 2006) on all

234 eigenvalues. Furthermore, individual ancestry proportions were estimated

235 with the sparse Non-negative Matrix Factorization method (sNMF) (Frichot

236 et al., 2014). We tested values of $\mathrm{K}$ between 1 and 8, performing 100

237 repetitions for each $\mathrm{K}$ value. All calculations were performed in RStudio

238 version 1.1.383 and R version 3.4.4 and the PCA and sNMF were

239 performed using the package LEA (Frichot and François, 2015). 
$242 \quad$ Given that our sampling included different species and populations

243 within species, we used the SNP data to reconstruct a species and

244 population tree describing the relationships between the populations using

245 TreeMix (Pickrell and Pritchard, 2012). We explored a scenario with no

246 migration, as well as models allowing for up to two migration events. Since

247 we do not have an outgroup, the position of the root was not specified, and

248 thus the resulting trees are unrooted.

250 Effect of linked SNPs

251 It is noteworthy that PCA, sNMF and TreeMix methods assume that

252 SNPs are independent, and thus results can be affected by linked SNPs in

253 our dataset. Given the absence of a reference genome, we lack information

254 on the location of the SNP markers. To verify if the results were influenced

255 by potential linkage of SNP markers, we produced a dataset by dividing

256 each scaffold of the catalog into blocks of 200 base pairs, which is larger

257 than the mean size of GBS loci. We then selected the SNP with less

258 missing data per block to generate a dataset with a single SNP per block.

259 Using this "single SNP" dataset, we repeated the three aforementioned

260 analysis. 
263 To test for possible past introgression between S. carolitertii and S.

264 pyrenaicus in the northern area of $S$. pyrenaicus distribution, we used the

265 D-statistic (Durand et al., 2011), which was used to distinguish between

266 ancestral polymorphism and introgression by looking at four different

267 populations related through a fixed species tree: two sister populations (P1

268 and P2), a third population that could be the source of introgressed genes

269 (P3) and has a common ancestor to P1 and P2, and one outgroup (Pout).

270 We explored four different possible species trees to perform different tests.

271 In scenario A, we tested for introgression between S. carolitertii (P3) and

272 two sister populations (P1 and P2) from S. pyrenaicus, one from the

273 northern and another from the southern part of its distribution. In B, we

274 tested if $S$. pyrenaicus populations from the south (P3) are more closely

275 related to $S$. carolitertii (P1) or populations from the northern part of $S$.

276 pyrenaicus distribution (P2). Considering the possibility of a geographical

277 cline in admixture proportions between S. carolitertii and S. pyrenaicus in

278 the northern part of S. pyrenaicus distribution, we also tested if the

279 northernmost sampling site of S. pyrenaicus (P3, Ocreza - see Figure 1)

280 showed more signs of introgression with S. carolitertii (P1) than the other

281 northern S. pyrenaicus (P2, scenario C). The opposite (all northern S.

282 pyrenaicus as sister populations $\mathrm{P} 1$ and $\mathrm{P} 2$ and S. carolitertii as the

283 potential source of introgressed genes P3) corresponds to scenario D. In all

284 cases, the outgroup (Pout) was either S. torgalensis or S. aradensis. All

285 possible combinations of the populations shown in the figure were tested.

286 We used S. pyrenaicus Almargem as the southern S. pyrenaicus 
population as S. pyrenaicus Guadiana was represented by only one individual after removing individuals with more than $50 \%$ missing data (see results). Significance of D-statistic values was assessed using a jackknife approach, dividing the dataset into 25 blocks and converting z-scores into $p$-values assuming a standard normal distribution $(p<0.01)$. These computations were done in RStudio version 1.1.383 and $\mathrm{R}$ version 3.4.4 using custom scripts, available at Dryad.

If introgression between populations occurred in the relatively recent past, we would expect individuals within the same population to show different degrees of introgression. To test this hypothesis, we calculated the D-statistic for each individual of P2 for the same scenarios as above.

\section{Demographic modelling of the divergence of S. carolitertii and S.}

\section{pyrenaicus}

We compared alternative divergence scenarios of the northern $S$. pyrenaicus from S. carolitertii and the southern S. pyrenaicus to test and quantify past introgression events. We used the composite likelihood method based on the joint site frequency spectrum (SFS) implemented in fastsimcoal2 version 2.6 (Excoffier et al., 2013). First, we compared the fit of three models to the observed SFS: "Admixture", "No Admixture C-PN" and "No Admixture PN-PS". The Admixture model assumes that the northern S. pyrenaicus received a contribution alpha (a) from the southern

S. pyrenaicus and 1-alpha (1-a) from S. carolitertii at the time of the split. Note that the estimates of alpha not only indicate the most likely species 
311 tree but also quantify the level of introgression. If alpha=0 then the northern

312 S. pyrenaicus is more closely related to $S$. carolitertii, whereas if alpha $=1$

313 then the northern and southern S. pyrenaicus are closer to each other.

314 Values of alpha in between 0 and 1 indicate that the northern S. pyrenaicus

315 received a contribution from both species, and hence indicate introgression.

316 We compared the likelihood of this admixture model to two models without

317 admixture. In the "No Admixture C-PN" model, S. carolitertii (C) and the

318 northern S. pyrenaicus (PN) share a more recent common ancestor. On the

319 other hand, in the "No Admixture PN-PS", the northern (PN) and southern

320 S. pyrenaicus (PS) have a more recent common ancestor. To be able to

321 compare the likelihood values directly, models need to have the same

322 number of parameters. Thus, to ensure the same number of parameters, in

323 the models without admixture we allowed for a bottleneck associated with

324 the split of the northern S. pyrenaicus from S. carolitertii and the southern

325 S. pyrenaicus, respectively, mimicking a founder effect. All parameters

326 were scaled in relation to a reference effective size, which was arbitrarily

327 set to be the effective size $(\mathrm{Ne})$ of $\mathrm{S}$. carolitertii. Considering the results of

328 this first three models, we then compared the fit of three more complex

329 models to distinguish between a hybrid origin of the northern S. pyrenaicus

330 and a secondary contact: "Hybrid Origin", "C-PN + Sec Contact PS-PN" and

331 "PN-PS + Sec Contact C-PN". The "Hybrid Origin" model is identical to the

332 previous "Admixture" model. However, to ensure the same number of

333 parameters as the two other models, we allowed for a bottleneck after the

334 split and hybridization, mimicking a founder event. The "C-PN + Sec 
335 Contact PS-PN" model assumes that $S$. carolitertii $(C)$ and the northern $S$.

336 pyrenaicus (PN) share a more recent common ancestor followed by a

337 secondary contact between southern and the northern S. pyrenaicus (PS-

338 PN). Finally, the "PN-PS + Sec Contact C-PN" model assumes that the

339 northern (PN) and the southern (PS) S. pyrenaicus share a more recent

340 common ancestor followed by a secondary contact between S. carolitertii

341 and the northern S. pyrenaicus (C-PN).

343 3D-SFS by sampling 3 individuals from $S$. carolitertii and the southern $S$.

344 pyrenaicus, and 4 individuals from the northern S. pyrenaicus. Given the

345 lack of an outgroup, we could not identify the ancestral state of alleles and

346 hence used the minor allele frequency spectrum. To sample individuals

347 without missing data, we used the initial dataset but without the MAF filter,

348 and each scaffold was divided into blocks of 200bp (which is larger than the

349 average length of the GBS loci). For each block we sampled the individuals

350 from each population with less missing data keeping only the sites with

351 data across all individuals. Given that the SFS is affected by the depth of

352 coverage, only genotypes with a depth of coverage $>10 x$ were used

353 (Nielsen et al., 2011). This resulted in an observed SFS with 7,047 SNPs.

354 For each model we performed 100 independent runs with 100 cycles,

355 approximating the SFS with 100,000 coalescent simulations. To convert the

356 relative divergence times estimated into absolute time in million years

357 (Mya), we assumed a generation time of 3 years for these species

358 (Magalhães et al., 2003; Almada and Sousa-Santos, 2010). 
364 reads per individual. After mapping all the reads from each individual to the 365 catalog, the median depth of coverage per sample was $47 x$. Filtering based

366 on MAF $\geq 0.01$ and depth of coverage between $1 / 4$ to $4 x$ of the individual

367 median resulted in 19 individuals with more than $50 \%$ of missing data,

368 which were removed. The final dataset had a total of 25,353 SNPs, with

$36940.32 \%$ missing data, and was comprised of 46 individuals, as follows: $S$.

370 carolitertii $(n=10)$, S. pyrenaicus Ocreza $(n=6)$, S. pyrenaicus Lizandro

$371(n=4), S$. pyrenaicus Canha $(n=6), S$. pyrenaicus Almargem $(n=5), S$.

372 pyrenaicus Guadiana $(n=1)$, S. torgalensis $(n=9), S$. aradensis $(n=5)$.

374 Characterization of the global patterns of genetic differentiation

The pairwise $\mathrm{F}_{\mathrm{ST}}$ estimates of genetic differentiation between

376 sampling locations are shown in Table 1. Overall, the higher levels of

377 genetic differentiation are between the two southwestern species ( $S$.

378 torgalensis and S. aradensis) and the two more widely distributed species

379 (S. carolitertii and S. pyrenaicus) $\left(F_{S T}>0.352\right)$. On the other hand, we find

380 the lower levels of genetic differentiation within northern S. pyrenaicus and 
between them and S. carolitertii $\left(\mathrm{F}_{\mathrm{ST}}<0.165\right)$. Indeed, we find lower levels of genetic differentiation between the northern S. pyrenaicus and S. carolitertii

$383\left(\mathrm{~F}_{\mathrm{ST}}<0.165\right)$ than between the northern and the southern S. pyrenaicus

384 ( $\left.F_{S T}>0.201\right)$. Interestingly, the levels of differentiation found between both

385 S. carolitertii and the northern S. pyrenaicus and the southern S. pyrenaicus are comparable to those found between $S$. torgalensis and $S$. aradensis.

The PCA results show that the first three principal components

389 explain approximately $26 \%$ of the variation (Figure S2A), although the

390 Tracy-Widom tests (Patterson et al., 2006) indicate that the first five

391 components have a significant effect $(p<0.01)$ (Figure S2B). We only show

392 the first three PCs because these have a clear biological interpretation. The

393 first principal component (Figure 2A and 2B) explains the higher

394 percentage of the variance $(\approx 16 \%)$ and clearly separates two groups: one

395 formed by S. carolitertii and S. pyrenaicus and another formed by $S$.

396 aradensis and $S$. torgalensis. This is consistent with the higher pairwise $F_{S T}$

397 values obtained between these two groups. The second principal

398 component (PC2) explains a much lower percentage of the variance $(\approx 6 \%)$

399 and separates $S$. aradensis from S. torgalensis (Figure $2 \mathrm{~A}$ and $2 \mathrm{C}$ ). Finally,

400 PC3 affects $S$. carolitertii and S. pyrenaicus and separates the southern $S$.

401 pyrenaicus from a cluster formed by S. carolitertii and the northern $S$.

402 pyrenaicus (Figure 2B and $2 \mathrm{C}$ ). It is not possible to distinguish between

403 individuals from S. carolitertii and the different sampling locations of

404 northern S. pyrenaicus. 
The estimation of ancestry proportions and the most likely number

406 of clusters with sNMF (Frichot et al. 2014) suggests that the data are

407 consistent with four populations (Figure 3), with $\mathrm{K}=4$ having the smallest

408 cross-entropy value (Figure S3). Interestingly, while individuals from the

409 two southwestern species (S. aradensis and S. torgalensis) are clustered

410 according to their species, individuals from $S$. carolitertii and the northern $S$.

411 pyrenaicus are clustered together, whereas the southern S. pyrenaicus

412 form a fourth cluster (Figure 3). Three individuals from S. pyrenaicus

413 Almargem appear to share a high ancestry proportion with S. carolitertii and

414 the northern S. pyrenaicus. However, these particular individuals have the

415 higher percentages of missing data in that location. Moreover, virtually all

416 individuals in the dataset exhibit some small proportion from groups other

417 than the one they are assigned to, which can be due to statistical noise or

418 shared ancestral polymorphism.

420 Inference of a population and species tree

$421 \quad$ We inferred a species tree based on the covariance of allele

422 frequencies across all SNPs, modelling changes in allele frequencies

423 through time due to genetic drift using TreeMix (Pickrell and Pritchard,

424 2012). This unrooted tree (Figure 4) shows a clear separation between two

425 groups: one comprising $S$. aradensis and $S$. torgalensis and the other

426 comprising S. carolitertii and S. pyrenaicus. Moreover, S. aradensis and S.

427 torgalensis appear as sister species, in accordance with the $\mathrm{F}_{\mathrm{ST}}, \mathrm{PCA}$ and 
428 sNMF results. Within the group of $S$. carolitertii and S. pyrenaicus, we

429 found two main lineages: the southern S. pyrenaicus (here represented by

430 S. pyrenaicus Almargem) and the one of $S$. carolitertii and the northern $S$.

431 pyrenaicus. This is in agreement with the PCA and sNMF, where these two

432 clusters were also detected, as well as with the $\mathrm{F}_{\mathrm{ST}}$ results that indicated a

433 lower level of differentiation between northern S. pyrenaicus populations

434 and S. carolitertii than between northern and southern S. pyrenaicus

435 populations. Attempts to produce a species tree with one or two migration

436 events were unsuccessful as different runs of the TreeMix program did not

437 produce consistent results.

\section{Effect of linked SNPs}

To verify if the results were influenced by the fact that some SNPS

441 could be linked, we produced a dataset with only one SNP per block of 200

442 base pairs. This dataset comprised 3,901 SNPs and the overall percentage

443 of missing data was $\approx 42.48 \%$. The results of PCA, sNMF and TreeMix

444 analysis were consistent with those from the initial dataset of 25,353 SNPs

445 (Figures S4- S7). This indicates that our results are not influenced by the

446 possibility that some SNPs are linked. Hence, further analyses were done

447 using the initial dataset. 
451 population are displayed in Figure 5. The exact number of SNPs that

452 showed the ABBA or BABA pattern and $p$-values can be found in Table S4.

To test for introgression between S. carolitertii and S. pyrenaicus,

454 we used the first topology, where the two S. pyrenaicus groups are sister

455 species, with S. carolitertii as the source of potential introgression (Figure

$4565 A)$. We obtained significantly positive values of $D$ for all population

457 combinations, independently of the outgroup used, reflecting an excess of

458 sites where northern S. pyrenaicus populations (P2) share the same allele

459 with $S$. carolitertii (P3), which can be interpreted as a sign of introgression

460 or a more recent shared ancestry. On the other hand, when we tested the

461 hypothesis that $S$. carolitertii and the northern S. pyrenaicus share a more

462 recent ancestry, most of the combinations of sampling locations resulted in

463 positive D-statistic values; however, these were not significantly different

464 from zero for most comparisons (Figure $5 \mathrm{~B}$ ). The exception was the

465 significant positive values of $D$ when the northern S. pyrenaicus population

466 is Ocreza. The overall pattern is in agreement with those from the PCA and

467 sNMF and with the species tree inferred with TreeMix, suggesting that $S$.

468 carolitertii and northern S. pyrenaicus share a more recent common

469 ancestor, even though the trend for positive (non-significant) D values is

470 consistent with gene flow between northern and southern S. pyrenaicus

471 and/or between S. carolitertii and northern S. pyrenaicus.

If $S$. carolitertii diverged at different times from the northern $S$.

473 pyrenaicus populations, or if introgression occurred after divergence of the 
474 different northern S. pyrenaicus populations, we would expect differences

475 in D-statistics among the northern S. pyrenaicus. To investigate the

476 possibility of such a geographical cline, we tested whether the

477 northernmost sampling location of $S$. pyrenaicus (Ocreza) is closer to $S$.

478 carolitertii than the other northern S. pyrenaicus locations, by computing D-

479 statistics according to a topology where S. carolitertii and S. pyrenaicus

480 Ocreza are sister populations. The estimated D-values were always

481 significantly positive (Figure $5 \mathrm{C}$ ), indicating that $S$. pyrenaicus Ocreza

482 shares more alleles with the other northern $S$. pyrenaicus than with $S$.

483 carolitertii. Contrarily, when the sister populations are both from the

484 northern area of $S$. pyrenaicus distribution and P3 is $S$. carolitertii, D is

485 never significantly different from zero (Figure 5D). This indicates that $S$.

486 pyrenaicus Ocreza is not closer to $S$. carolitertii, suggesting that all northern

487 S. pyrenaicus populations share similar numbers of derived alleles with $S$.

488 carolitertii. This is consistent with the species tree inferred with TreeMix,

489 showing that all northern S. pyrenaicus have a common ancestor that

490 diverged from S. carolitertii after the divergence of the southern $S$.

491 pyrenaicus (Figure 4). However, a scenario of introgression between $S$.

492 carolitertii and the ancestor of the northern S. pyrenaicus (i.e. prior to the

493 divergence of the different northern S. pyrenaicus populations) can also

494 explain these results.

495 In the case of recent introgression events, we would expect to find

496 differences in the D-statistic values among individuals from a given

497 population. To detect evidence of such relatively recent introgression 
498 between species, we computed the D-statistic by individual (Figure S8 and

499 Table S5). Overall, we found no significant variation among different

500 individuals from the same population, suggesting that introgression events

501 are likely pre-dating the divergence of populations.

502

503 Demographic modelling of divergence of S. carolitertii and S.

\section{4 pyrenaicus}

505 For the first three models tested (Figure 6 A-C), which were intended at

506 investigating whether an introgression scenario was a better fit for the data

507 than a simply bifurcating tree, the "Admixture" models achieved a higher

508 likelihood than the models without admixture ("No admixture C-PN" and "No

509 admixture PN-PS") (Figure 6 and Table S6), suggesting that the northern $S$.

510 pyrenaicus received a contribution from both $S$. carolitertii and the southern

511 S. pyrenaicus. Estimates under this model indicate that, at the time of the

512 split, the northern S. pyrenaicus received a contribution of $11.35 \%$ from the

513 southern S. pyrenaicus and the remaining $88.65 \%$ from S. carolitertii

514 (Figure 6A). This model suggests that the three populations have similar

515 population sizes, although slightly lower for the southern S. pyrenaicus,

516 large ancestral sizes for both species and a relatively recent split of the

517 northern S. pyrenaicus, approximately $10 \%$ of the split time of S. carolitertii

518 and southern S. pyrenaicus (Table S7-A).

519 Based on this result, we compared three models to distinguish

520 between a scenario of hybrid origin of the northern S. pyrenaicus and 
521 secondary contact (Figure 6 D-F). We obtained very similar likelihoods

522 between models, although the model where the northern S. pyrenaicus

523 originates via a simultaneous contribution of $S$. carolitertii and the northern

524 S. pyrenaicus ("Hybrid Origin") achieving a slightly higher likelihood (Figure

5256 and Table S6). Under this model, we estimated that, at the time of its

526 origin, the northern $S$. pyrenaicus received a contribution of $90.78 \%$ from $S$.

527 carolitertii and $9.22 \%$ from the southern S. pyrenaicus (Figure 6D). Despite

528 the fact that this model has a slightly higher likelihood, we note that the

529 difference in likelihood between these three models is small, and hence,

530 with current data, we have no power to clearly distinguish between a hybrid

531 origin and a secondary contact. The three models indicate overall similar

532 relative times (Table S7B), although the second-best model ("PN-PS + Sec

533 Contact PN-C") infers an older divergence time of the northern $S$.

534 pyrenaicus than the other models. 
556 Santos et al., 2019). At that time, the configuration of the river systems in

557 the Iberian Peninsula was very different from today, characterized by many

\section{Discussion}

between populations of $S$. carolitertii, S. pyrenaicus, S. torgalensis and S. aradensis using genome-wide data (SNPs) obtained through Genotyping by Sequencing, as well as test for the possibility of past introgression between $S$. carolitertii and $S$. pyrenaicus in the northern part of $S$. pyrenaicus distribution. We successfully obtained a high-quality set of SNP markers for these four species from GBS data without a reference genome.

\section{Inferring a species tree from population genomic data}

Taken together, our results indicate a species tree composed of two main lineages: (i) S. torgalensis and $S$. aradensis and (ii) S. carolitertii and S. pyrenaicus. This is evidenced by the pairwise $\mathrm{F}_{\mathrm{ST}}$ (Table 1), as well as by the PCA results (Figure 2), and the species tree inferred with TreeMix (Figure 4). This finding is in agreement with phylogenies previously obtained for cytochrome b (Brito et al., 1997; Sanjur et al., 2003; Mesquita et al., 2007; Perea et al., 2010, 2016; Sousa-Santos et al., 2019) and nuclear genes (Almada and Sousa-Santos, 2010; Waap et al., 2011; Sousa-Santos et al., 2019). Recent estimates based on one mitochondrial, seven nuclear genes and fossil calibration place the divergence between the two main lineages at approximately 14 Million years ago (Mya) (Sousa- 
558 endorheic basins (river basins that did not flow to the ocean, but instead to

559 lakes). Various Iberian rivers (e.g. Tagus, Guadiana) were composed of

560 several endorheic lakes, instead of having a continuous flow to the ocean.

561 It has been proposed that the isolation of the ancestral of the species in

562 one of those endorheic basins (the Lower Tagus paleobasin, approximately

563 in the current location of the Tagus river mouth - see Sousa-Santos et al.,

5642019 for a map of the Iberian endorheic basins) led to the differentiation of

565 the S. aradensis and S. torgalensis lineage, whose ancestor posteriorly

566 migrated south, to the current distributions of the two species (Sousa-

567 Santos et al., 2007, 2019). The isolation and differentiation of the ancestral

568 into S. torgalensis and $S$. aradensis in distinct river basins might have then

569 been facilitated by the uplift of a mountain range in the area (the Caldeirão

570 mountains in the south of Portugal) (Mesquita et al., 2005), with the most

571 recent estimates of their divergence pointing to 4 Mya (Sousa-Santos et al., 572 2019).

573 For the second lineage, comprising S. carolitertii and S. pyrenaicus,

574 we find overall relatively lower genetic differentiation between the northern

575 S. pyrenaicus and S. carolitertii than between northern and southern $S$.

576 pyrenaicus (Table 1 and Figures 2 and 3) and the species tree inferred with

577 TreeMix (Figure 4) shows a more recent common ancestor between $S$.

578 carolitertii and the northern S. pyrenaicus. These results could, in principle,

579 be explained by two different scenarios: (i) $S$. carolitertii and the northern $S$.

580 pyrenaicus share a more recent common ancestor but evolved 
581 independently in the absence of gene flow; (ii) the northern S. pyrenaicus

582 appear closer to $S$. carolitertii due to extensive introgression between them.

584 Introgression between S. carolitertii and S. pyrenaicus

$585 \quad$ Previous studies suggested the possibility of introgression to explain

586 incongruent topologies obtained with nuclear and mitochondrial markers

587 (Waap et al., 2011; Sousa-Santos et al., 2019) and described S. pyrenaicus

588 as paraphyletic in relation to $S$. carolitertii (Sousa-Santos et al. 2019). Our

589 results indicate that introgression very likely occurred between S. carolitertii

590 and S. pyrenaicus, which reconciles discrepancies in previous results of

591 mitochondrial and nuclear markers.

592 Our estimates from the demographic modelling based on the joint

593 three population site frequency spectrum showed that a scenario of

594 introgression is more likely than one without any gene flow (Figure 6A-C),

595 indicating that the divergence of S. pyrenaicus and S. carolitertii involved

596 events of introgression, and thus the species tree cannot be simply

597 explained by a bifurcating tree. These are simple models but, nonetheless,

598 indicate that northern S. pyrenaicus seems to be a mixture of $S$. carolitertii

599 and the southern S. pyrenaicus lineage, with a higher proportion from $S$.

600 carolitertii. This could explain why S. pyrenaicus from the Tagus, Guadiana

601 and adjacent small basins cluster together in previously inferred mtDNA

602 phylogenies (Brito et al., 1997; Mesquita et al., 2007) but seem to group in

603 different clusters on nuclear (Waap et al., 2011; Sousa-Santos et al., 2019) 
604 and genome-wide data (this study). The fact that we infer a relatively small

605 admixture contribution from the southern S. pyrenaicus is probably the

606 reason why this introgression was not detected with the D-statistics for all

607 the northern S. pyrenaicus populations used (Figure 5B). However, D-

608 values tend to be positive and are in fact significant when the northern $S$.

609 pyrenaicus population is Ocreza, suggesting some shared alleles between

610 northern and southern S. pyrenaicus, which would not be expected in the

611 case of a simple bifurcating tree where $S$. carolitertii and the northern $S$.

612 pyrenaicus share a more recent common ancestor. Moreover, the

613 consistency of the results obtained for the D-statistic independently of the

614 northern S. pyrenaicus used indicates that the introgression had to be older

615 than the isolation of different populations in tributaries of the Tagus basin

616 (Ocreza and Canha, on opposite margins of the main river). In fact, the

617 introgression had to be older than the isolation of $S$. pyrenaicus in Lizandro,

618 which is a small independent basin and is not connected to the Tagus,

619 although it might have been colonized from there, at a time when

620 connections were still present, as it has been hypothesised for other small

621 basin nearby (Colares) (Sousa-Santos et al., 2007).

622 The "Hybrid Origin" model (Figure 6D) assumes that the time of the

623 admixture with the southern $S$. pyrenaicus is the same as with $S$. carolitertii,

624 which corresponds to a scenario of hybrid speciation. Indeed, this result

625 raises the possibility that $S$. pyrenaicus from Tagus drainage is the result of

626 hybridization between the southern S. pyrenaicus lineage and S. carolitertii,

627 which could have happened during the changes of endorheic paleo- 
628 drainage systems. Hybrid speciation has been invoked in several instances

629 to explain incongruences between nuclear and mtDNA markers and has

630 been proposed in various organisms (e.g. Hermansen et al., 2011; Leducq

631 et al., 2016; Lamichhaney et al., 2018), including freshwater fish species

632 (e.g. Gila, DeMarais et al., 1992; Cottus, Nolte et al., 2005).

634 could not be discarded. Despite the fact the "Hybrid Origin" model achieves

635 a higher likelihood, we note that there is a small difference between the

636 likelihood of the models of hybrid speciation and secondary contact (Figure

$6376 \mathrm{D}-\mathrm{F})$. Therefore, we are not able to distinguish between the two scenarios

638 with certainty. A scenario of secondary contact would have been possible if,

639 for example, after S. pyrenaicus was already disseminated throughout the

640 Tagus and southern drainages (e.g. Guadiana), connections were re-

641 established between the Tagus and the northern basins, allowing gene flow

642 between S. carolitertii and S. pyrenaicus. The geological record seems to

643 indicate that river connections were maintained until later in time between

644 the Douro paleobasin and the paleobasin in the current location of the

645 Tagus spring (Upper Tagus paleobasin) than between that and the

646 Guadiana (Sousa-Santos et al., 2019), which could have allowed the

647 secondary contact between the northern S. pyrenaicus and S. carolitertii.

648 This would be in agreement with the "PN-PS + Sec Contact C-PN" model,

649 which achieves the second highest likelihood amongst the three more

650 complex models (Table S6). 
$651 \quad$ Whether the genomic patterns observed in the northern $S$.

652 pyrenaicus are the result of hybrid speciation or a secondary contact, a

653 genome with contributions from different species provides genetic diversity

654 upon which natural selection can act (Martin and Jiggins, 2017). While

655 introgression can generate negative fitness effects resulting of

656 incompatibilities between loci from the different species, it also possible that

657 introgression brings beneficial alleles which might help the population to

658 better cope with the environment (Martin and Jiggins, 2017). Although signs

659 of adaptation to the different climatic types of the Iberian peninsula (Atlantic

660 in the north and Mediterranean in the south) have been investigated in

661 Iberian Squalius (Jesus et al., 2017), the northern S. pyrenaicus

662 populations have not been examined so far. Therefore, it remains to be

663 investigated if having a genome with contributions from different species

664 provides an advantage to the northern S. pyrenaicus, as has been found in

665 other species (e.g., in swordtail fish, hybrids between two species living at

666 different altitudes seem to be better adapted to intermediate altitudes

667 (Culumber et al., 2012)). Nonetheless, the system provides an exciting

668 opportunity for future work to answer fundamental questions on the

669 consequences of hybridization at the genome level.

670

671

672 Conclusions 
673 In face of the incongruent results between mitochondrial and

674 nuclear markers, previous studies have suggested that populations from

675 the Tagus river basin could correspond to a new taxon (Waap et al., 2011;

676 Sousa-Santos et al., 2019). Overall, our results indicate that the patterns

677 observed in the Tagus are most likely the result of introgression. Although

678 the "Hybrid Origin" model has the best likelihood, we note that the fit to the

679 SFS is not perfect (Figure S9). This suggests that the mode of speciation

680 can be even more complex, e.g. involving further changes in the past

681 effective sizes. Whole-genome data would be required to obtain more

682 SNPs to distinguish between a hybrid origin for the northern S. pyrenaicus

683 and secondary contact.

684 Our work shows evidence for past gene flow between currently

685 allopatric freshwater fish species, estimating that the northern populations

686 of S. pyrenaicus received approximately $90 \%$ from S. carolitertii.

687 Furthermore, our results illustrate that even in freshwater species currently

688 found in isolated river drainages, divergence can be more complex than a

689 simply allopatric model, involving periods of past gene flow. This illustrates

690 how the use of population genomics data based on SNP polymorphisms

691 could detect past gene flow events and resolve species evolutionary

692 history. Moreover, this work adds to the growing list of examples where

693 hybridization has been reported and opens the door to future studies to

694 elucidate how such "hybrid"/introgressed genomes cope with

695 incompatibilities, but also can have a higher potential to adapt to new

696 environments due to their increased genetic diversity. 


\section{Acknowledgements}

698 We would like to thank Tiago Jesus and Miguel Machado for the

699 preparation of the samples. This work was funded by the strategic project

700 UID/BIA/00329/2013 (2015-2018) and UID/BIA/00329/2019 granted to

701 cE3c from the Portuguese National Science Foundation, Fundação para a

702 Ciência e a Tecnologia. VCS is funded by EU H2020 programme (Marie

703 Sklodowska-Curie grant 799729).

704

705 Conflict of interest

706 The authors declare that they have no conflict of interest.

707

708 
709

710

711

712

715

716

717

718

719

720

721

\section{References}

Almada V, Sousa-Santos C (2010). Comparisons of the genetic structure of Squalius populations (Teleostei, Cyprinidae) from rivers with contrasting histories, drainage areas and climatic conditions based on two molecular markers. Mol Phylogenet Evol 57: 924-931.

Andrews KR, Good JM, Miller MR, Luikart G, Hohenlohe PA (2016). Harnessing the power of RADseq for ecological and evolutionary genomics. Nat Rev Genet 17: 81-92.

Bagley RK, Sousa VC, Niemiller ML, Linnen CR (2017). History, geography and host use shape genomewide patterns of genetic variation in the redheaded pine sawfly ( Neodiprion lecontei ). Mol Ecol 26: 10221044.

Barluenga M, Stölting KN, Salzburger W, Muschick M, Meyer A (2006). Sympatric speciation in Nicaraguan crater lake cichlid fish. Nature 439: 719-723.

Brito RM, Briolay J, Galtier N, Bouvet Y, Coelho MM (1997). Phylogenetic Relationships within Genus Leuciscus ( Pisces , Cyprinidae ) in Portuguese Fresh Waters, Based on Mitochondrial DNA Cytochrome b Sequences. Mol Phylogenet Evol 8: 435-442.

Catchen J, Hohenlohe PA, Bassham S, Amores A, Cresko WA (2013). Stacks: An analysis tool set for population genomics. Mol Ecol 22: 3124-3140. 
731 Coelho MM, Bogutskaya NG, Rodrigues JA, Collares-Pereira MJ (1998).

732 Leuciscus torgalensis, and L. aradensis, two new cyprinids for

$733 \quad$ Portuguese fresh waters. J Fish Biol 52: 937-950.

734 Coelho MM, Brito RM, Pacheco TR, Figueiredo D, Pires AM (1995).

735 Genetic variation and divergence of Leuciscus pyrenaicus and L.

$736 \quad$ carolitertii (Pisces, Cyprinidae). J Fish Biol 47: 243-258.

737 Culumber ZW, Shepard DB, Coleman SW, Rosenthal GG, Tobler M (2012).

$738 \quad$ Physiological adaptation along environmental gradients and replicated

739 hybrid zone structure in swordtails (Teleostei: Xiphophorus). J Evol

$740 \quad$ Biol 25: 1800-1814.

741 Danecek P, Auton A, Abecasis G, Albers CA, Banks E, DePristo MA, et al.

742 (2011). The variant call format and VCFtools. Bioinformatics 27: 2156-

7432158.

744 Dasmahapatra KK, Walters JR, Briscoe AD, Davey JW, Whibley A, Nadeau

$745 \quad \mathrm{NJ}$, et al. (2012). Butterfly genome reveals promiscuous exchange of

746 mimicry adaptations among species. Nature 487: 94-98.

747 Davey JW, Hohenlohe PA, Etter PD, Boone JQ, Catchen JM, Blaxter ML

748 (2011). Genome-wide genetic marker discovery and genotyping using

749 next-generation sequencing. Nat Rev Genet 12: 499-510.

750 DeMarais BD, Dowling TE, Marsh PC, Douglas ME, Minckley WL (1992).

751 Origin of Gila seminuda ( Teleostei $\square$ : Cyprinidae ) through

752 introgressive hybridization $\square$ : Implications for evolution and 
conservation. Evolution (N Y) 89: 2747-2751.

754 Durand EY, Patterson N, Reich D, Slatkin M (2011). Testing for ancient

755 admixture between closely related populations. Mol Biol Evol 28:

$756 \quad 2239-2252$.

757 Elshire RJ, Glaubitz JC, Sun Q, Poland JA, Kawamoto K, Buckler ES, et al.

758 (2011). A robust, simple genotyping-by-sequencing (GBS) approach

759 for high diversity species. PLoS One 6: 1-10.

760 Ewels P, Magnusson M, Lundin S, Käller M (2016). MultiQC: Summarize analysis results for multiple tools and samples in a single report. Bioinformatics 32: 3047-3048.

763 Excoffier L, Dupanloup I, Huerta-Sánchez E, Sousa VC, Foll M (2013). 764 Robust Demographic Inference from Genomic and SNP Data. PLoS Genet 9.

766 Figueiró H V., Li G, Trindade FJ, Assis J, Pais F, Fernandes G, et al. (2017). Genome-wide signatures of complex introgression and adaptive evolution in the big cats. Sci Adv 3: e1700299.

769 Frichot E, François O (2015). LEA: An R package for landscape and ecological association studies. Methods Ecol Evol 6: 925-929.

771 Frichot E, Mathieu F, Trouillon T, Bouchard G, François O (2014). Fast and efficient estimation of individual ancestry coefficients. Genetics 196:

$773973-983$.

774 Fu L, Niu B, Zhu Z, Wu S, Li W (2012). CD-HIT: Accelerated for clustering 
the next-generation sequencing data. Bioinformatics 28: 3150-3152.

776

777

778

779

780

781

782

783

784

Gagnaire PA, Pavey SA, Normandeau E, Bernatchez L (2013). The genetic architecture of reproductive isolation during speciation-with-gene-flow in lake whitefish species pairs assessed by rad sequencing. Evolution (N Y) 67: 2483-2497.

Gante HF, Matschiner M, Malmstrøm M, Jakobsen KS, Jentoft S, Salzburger W (2016). Genomics of speciation and introgression in Princess cichlid fishes from Lake Tanganyika. Mol Ecol 25: 61436161.

Garrison E, Marth G (2012). Haplotype-based variant detection from shortread sequencing. http://arxiv.org/abs/12073907.

Green RE, Krause J, Briggs AW, Maricic T, Stenzel U, Kircher M, et al. (2010). A Draft Sequence of the Neandertal Genome. Science (80- ) 328: $710-722$.

Henriques R, Sousa V, Coelho MM (2010). Migration patterns counteract seasonal isolation of Squalius torgalensis, a critically endangered freshwater fish inhabiting a typical Circum-Mediterranean small drainage. Conserv Genet 11: 1859-1870.

Hermansen JS, Sæther SA, Elgvin TO, Borge T, Hjelle E, Sætre GP (2011). Hybrid speciation in sparrows I: Phenotypic intermediacy, genetic admixture and barriers to gene flow. Mol Ecol 20: 3812-3822.

Hey J, Machado CA (2003). The study of structured populations - New 
hope for a difficult and divided science. Nat Rev Genet 4: 535-543.

798 Hohenlohe PA, Bassham S, Etter PD, Stiffler N, Johnson EA, Cresko WA

799 (2010). Population Genomics of Parallel Adaptation in Threespine

800 Stickleback using Sequenced RAD Tags (DJ Begun, Ed.). PLoS

$801 \quad$ Genet 6: e1000862.

802 Hohenlohe PA, Day MD, Amish SJ, Miller MR, Kamps-Hughes N, Boyer

803 MC, et al. (2013). Genomic patterns of introgression in rainbow and 804 westslope cutthroat trout illuminated by overlapping paired-end RAD sequencing. Mol Ecol 22: 3002-3013.

806 Hudson RR, Slatkint M, Maddison WP (1992). Estimation of Levels of Gene Flow From DNA Sequence Data. Genetics 589: 583-589.

808 Jesus TF, Moreno JM, Repolho T, Athanasiadis A, Rosa R, Almeida-Val 809 VMF, et al. (2017). Protein analysis and gene expression indicate 810 differential vulnerability of Iberian fish species under a climate change 811 scenario (S Rutherford, Ed.). PLoS One 12: e0181325.

812 Jones JC, Fan S, Franchini P, Schartl M, Meyer A (2013). The evolutionary 813 history of Xiphophorus fish and their sexually selected sword: A 814 genome-wide approach using restriction site-associated DNA 815 sequencing. Mol Ecol 22: 2986-3001.

816 Jones FC, Grabherr MG, Chan YF, Russell P, Mauceli E, Johnson J, et al. 817 (2012). The genomic basis of adaptive evolution in threespine $818 \quad$ sticklebacks. Nature 484: 55-61. 
819 Lamichhaney S, Berglund J, Almén MS, Maqbool K, Grabherr M, MartinezBarrio A, et al. (2015). Evolution of Darwin's finches and their beaks revealed by genome sequencing. Nature 518: 371-375.

822 Lamichhaney S, Han F, Webster MT, Andersson L, Grant BR, Grant PR 823 (2018). Rapid hybrid speciation in Darwin's finches. Science (80- ) $824 \quad 359: 224-228$.

825 Leducq JB, Nielly-Thibault L, Charron G, Eberlein C, Verta JP, Samani P, 826 et al. (2016). Speciation driven by hybridization and chromosomal 827 plasticity in a wild yeast. Nat Microbiol 1: 1-10.

828 Li H (2013). Aligning sequence reads, clone sequences and assembly 829 contigs with BWA-MEM. http://arxiv.org/abs/13033997.

$830 \mathrm{Li} \mathrm{H}$, Durbin $\mathrm{R}$ (2009). Fast and accurate short read alignment with 831 Burrows-Wheeler transform. Bioinformatics 25: 1754-1760.

832 Li W, Godzik A (2006). Cd-hit: A fast program for clustering and comparing 833 large sets of protein or nucleotide sequences. Bioinformatics 22: $834 \quad 1658-1659$.

835 Li H, Handsaker B, Wysoker A, Fennell T, Ruan J, Homer N, et al. (2009). 836 The Sequence Alignment/Map format and SAMtools. Bioinformatics 25: 2078-2079. history in the relationship between population dynamics and environmental variability in two Mediterranean stream fishes. $J$ Fish 
Biol 63: 300-317.

842 de Manuel M, Kuhlwilm M, Frandsen P, Sousa VC, Desai T, Prado-

$843 \quad$ Martinez J, et al. (2016). Chimpanzee genomic diversity reveals

$844 \quad$ ancient admixture with bonobos. Science (80- ) 354: 477-481.

845 Martin SH, Jiggins CD (2017). Interpreting the genomic landscape of $846 \quad$ introgression. Curr Opin Genet Dev 47: 69-74.

847 McManus KF, Kelley JL, Song S, Veeramah KR, Woerner AE, Stevison LS, 848 et al. (2015). Inference of gorilla demographic and selective history 849 from whole-genome sequence data. Mol Biol Evol 32: 600-612.

850 Meier JI, Sousa VC, Marques DA, Selz OM, Wagner CE, Excoffier L, et al. 851 (2017). Demographic modelling with whole-genome data reveals parallel origin of similar Pundamilia cichlid species after hybridization. Mol Ecol 26: 123-141.

854 Mesquita N, Cunha C, Carvalho GR, Coelho MM (2007). Comparative 855 phylogeography of endemic cyprinids in the south-west Iberian 856 Peninsula: Evidence for a new ichthyogeographic area. J Fish Biol 71: $45-75$. of the cyprinid Squalius aradensis and implications for conservation of the endemic freshwater fauna of southern Portugal. Mol Ecol 14: 1939-1954.

862 Nielsen R, Paul JS, Albrechtsen A, Song YS (2011). Genotype and SNP 
calling from next-generation sequencing data. Nat Rev Genet 12: 443451.

Nolte AW, Freyhof J, Stemshorn KC, Tautz D (2005). An invasive lineage of sculpins, Cottus sp. (Pisces, Teleostei) in the Rhine with new habitat adaptations has originated from hybridization between old phylogeographic groups. Proc R Soc B Biol Sci 272: 2379-2387.

Paris JR, Stevens JR, Catchen JM (2017). Lost in parameter space: a road map for stacks. Methods Ecol Evol 8: 1360-1373.

Patterson N, Price AL, Reich D (2006). Population structure and eigenanalysis. PLoS Genet 2: 2074-2093.

Perea S, Böhme M, Zupancic P, Freyhof J, Sanda R, Ozuluğ M, et al. (2010). Phylogenetic relationships and biogeographical patterns in Circum-Mediterranean subfamily Leuciscinae (Teleostei, Cyprinidae) inferred from both mitochondrial and nuclear data. BMC Evol Biol 10: 265.

Perea S, Cobo-Simon M, Doadrio I (2016). Cenozoic tectonic and climatic events in southern Iberian Peninsula: Implications for the evolutionary history of freshwater fish of the genus Squalius (Actinopterygii, Cyprinidae). Mol Phylogenet Evol 97: 155-169.

Pfenninger M, Patel S, Arias-Rodriguez L, Feldmeyer B, Riesch R, Plath M (2015). Unique evolutionary trajectories in repeated adaptation to hydrogen sulphide-toxic habitats of a neotropical fish (Poecilia 
mexicana). Mol Ecol 24: 5446-5459.

886 Pickrell JK, Pritchard JK (2012). Inference of Population Splits and Mixtures from Genome-Wide Allele Frequency Data. PLoS Genet 8.

888 Redenbach Z, Taylor EB (2002). Evidence for historical introgression along

889 a contact zone between two species of char (Pisces: Salmonidae) in 890 northwestern North America. Evolution (N Y) 56: 1021-1035.

891 Rochette NC, Rivera-Colón AG, Catchen JM (2019). Stacks 2: Analytical

$892 \quad$ Methods for Paired-end Sequencing Improve RADseq-based

893 Population Genomics. bioRxiv. www.biorxiv.org/content/10.1101/615385v1.

895 Sanjur OI, Carmona JA, Doadrio I (2003). Evolutionary and biogeographical 896 patterns within Iberian populations of the genus Squalius inferred from 897 molecular data. Mol Phylogenet Evol 29: 20-30.

898 Seehausen O, Butlin RK, Keller I, Wagner CE, Boughman JW, Hohenlohe 899 PA, et al. (2014). Genomics and the origin of species. Nat Rev Genet $900 \quad$ 15: $176-192$.

901 Seehausen O, Wagner CE (2014). Speciation in Freshwater Fishes. Annu 902 Rev Ecol Evol Syst 45: 621-651.

903 Sousa-Santos C, Collares-Pereira MJ, Almada V (2007). Reading the 904 history of a hybrid fish complex from its molecular record. Mol $905 \quad$ Phylogenet Evol 45: 981-996.

906 Sousa-Santos C, Jesus TF, Fernandes C, Robalo JI, Coelho MM (2019). 
Fish diversification at the pace of geomorphological changes: evolutionary history of western Iberian Leuciscinae (Teleostei: Leuciscidae) inferred from multilocus sequence data. Mol Phylogenet Evol 133: 263-285.

Sousa V, Hey J (2013). Understanding the origin of species with genomescale data: modelling gene flow. Nat Rev Genet 14: 404-414.

Taggart JB, Hynes RA, Prodöuhl PA, Ferguson A (1992). A simplified protocol for routine total DNA isolation from salmonid fishes. J Fish Biol 40: 963-965.

Terekhanova N V., Logacheva MD, Penin AA, Neretina T V., Barmintseva AE, Bazykin GA, et al. (2014). Fast Evolution from Precast Bricks: Genomics of Young Freshwater Populations of Threespine Stickleback Gasterosteus aculeatus. PLoS Genet 10.

vonHoldt BM, Cahill JA, Fan Z, Gronau I, Robinson J, Pollinger JP, et al. (2016). Whole-genome sequence analysis shows that two endemic species of North American wolf are admixtures of the coyote and gray wolf. Sci Adv 2: e1501714.

Waap S, Amaral AR, Gomes B, Coelho MM (2011). Multi-locus species tree of the chub genus Squalius (Leuciscinae: Cyprinidae) from western Iberia: New insights into its evolutionary history. Genetica 139: 1009-1018. 
bioRxiv preprint doi: https://doi.org/10.1101/585687; this version posted July 20, 2019. The copyright holder for this preprint (which was not certified by peer review) is the author/funder, who has granted bioRxiv a license to display the preprint in perpetuity. It is made available under aCC-BY-NC-ND 4.0 International license. 
bioRxiv preprint doi: https://doi.org/10.1101/585687; this version posted July 20, 2019. The copyright holder for this preprint (which was not certified by peer review) is the author/funder, who has granted bioRxiv a license to display the preprint in perpetuity. It is made available under aCC-BY-NC-ND 4.0 International license.

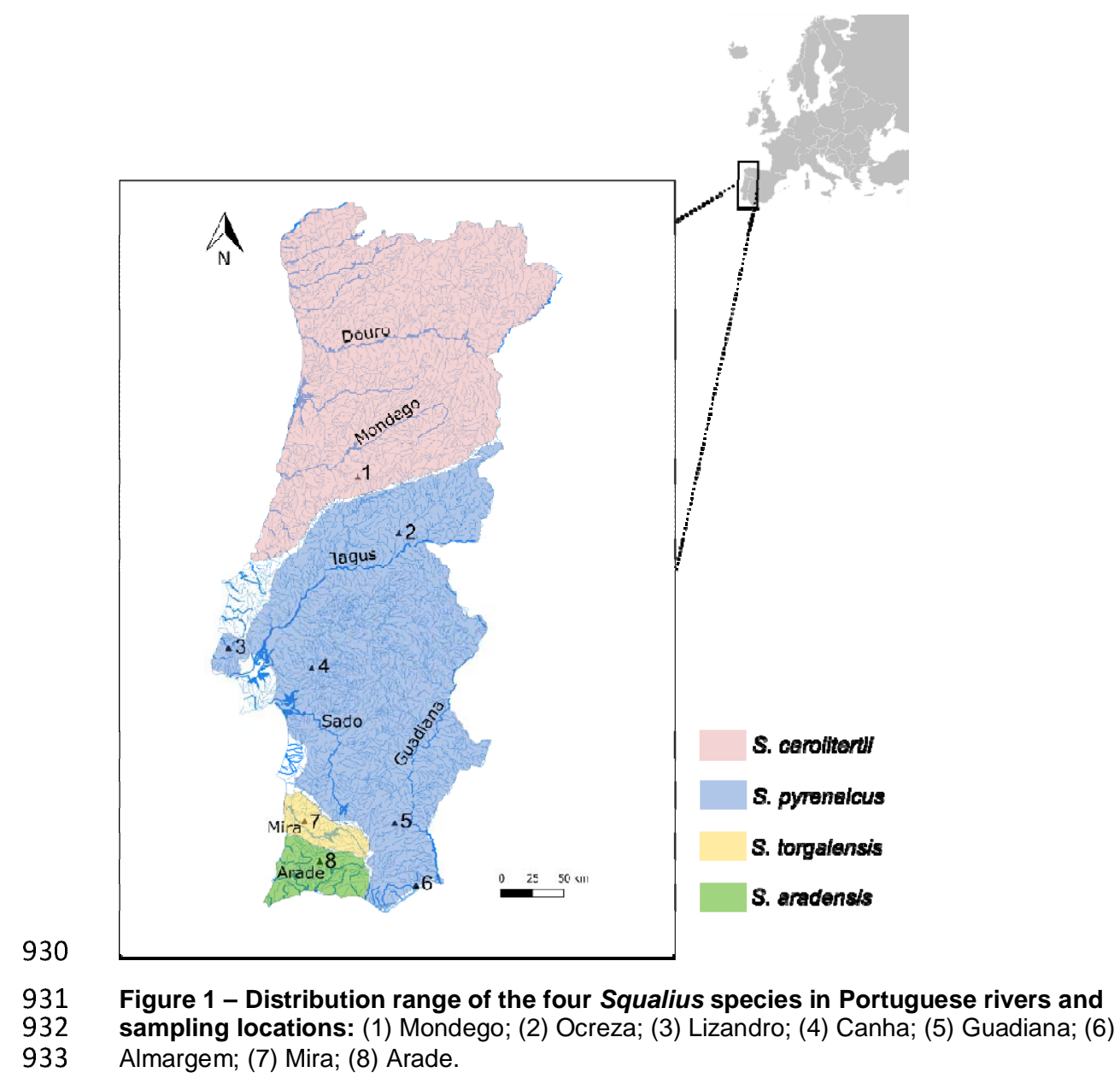

934

935 
bioRxiv preprint doi: https://doi.org/10.1101/585687; this version posted July 20,2019 . The copyright holder for this preprint (which was not certified by peer review) is the author/funder, who has granted bioRxiv a license to display the preprint in perpetuity. It is made available under aCC-BY-NC-ND 4.0 International license.

936

(A)

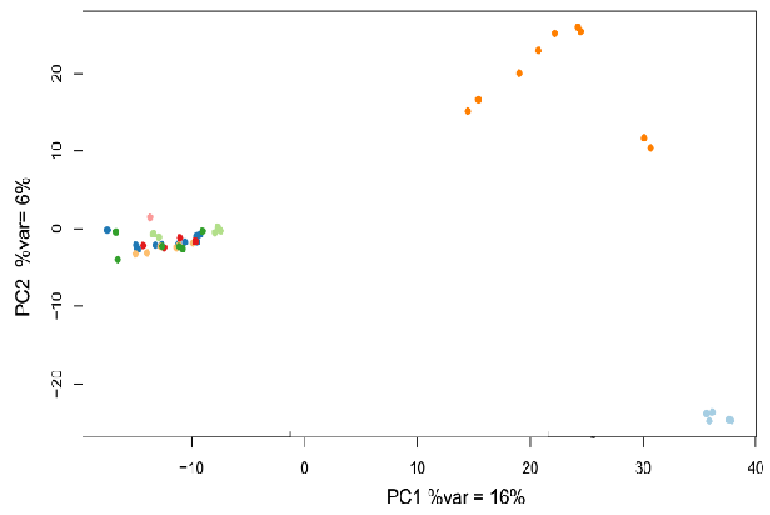

(C)

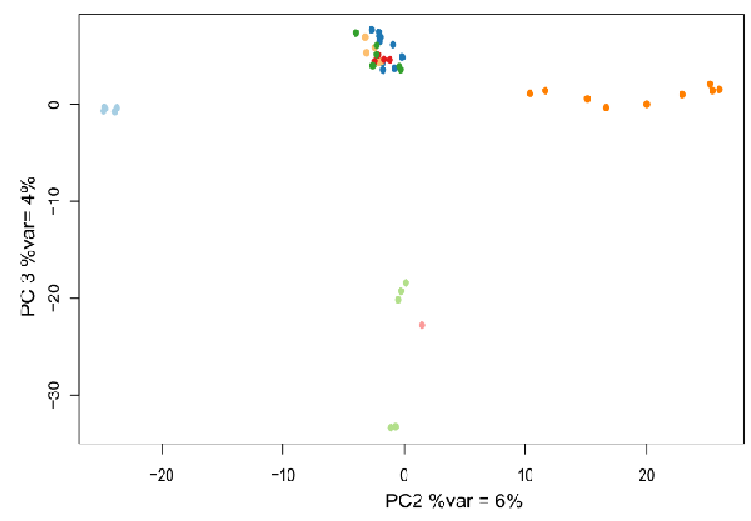

(B)

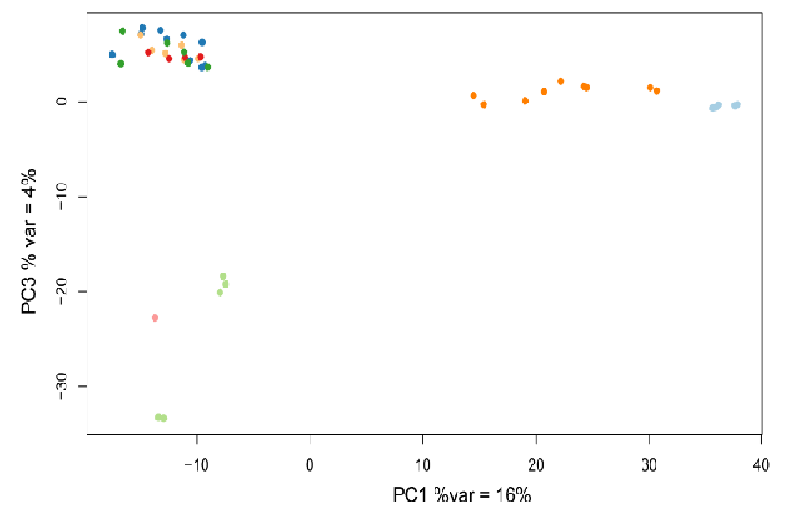

- S. aradensis

- S. torgalensis

- S. carolitertii

- S. pyrenaicus Ocreza

- S. pyrenaicus Lizandro

- S. pyrenaicus Canha

- S. pyrenaicus Almargem

- S. pyrenaicus Guadiana

Figure 2 - Results for the first three components of the Principal Components Analysis: (A) PC1 and PC2; (B) PC1 and PC3; (C) PC2 and PC3. Each point corresponds to one individual. The PCA was calculated based on the dataset with 25,353 SNPs, filtered with MAF $\geq 0.01$ and keeping only SNPs with a depth of coverage between $1 / 4$ and 4 times the individual median depth of coverage. 
bioRxiv preprint doi: https://doi.org/10.1101/585687; this version posted July 20,2019 . The copyright holder for this preprint (which was not certified by peer review) is the author/funder, who has granted bioRxiv a license to display the preprint in perpetuity. It is made available under aCC-BY-NC-ND 4.0 International license.

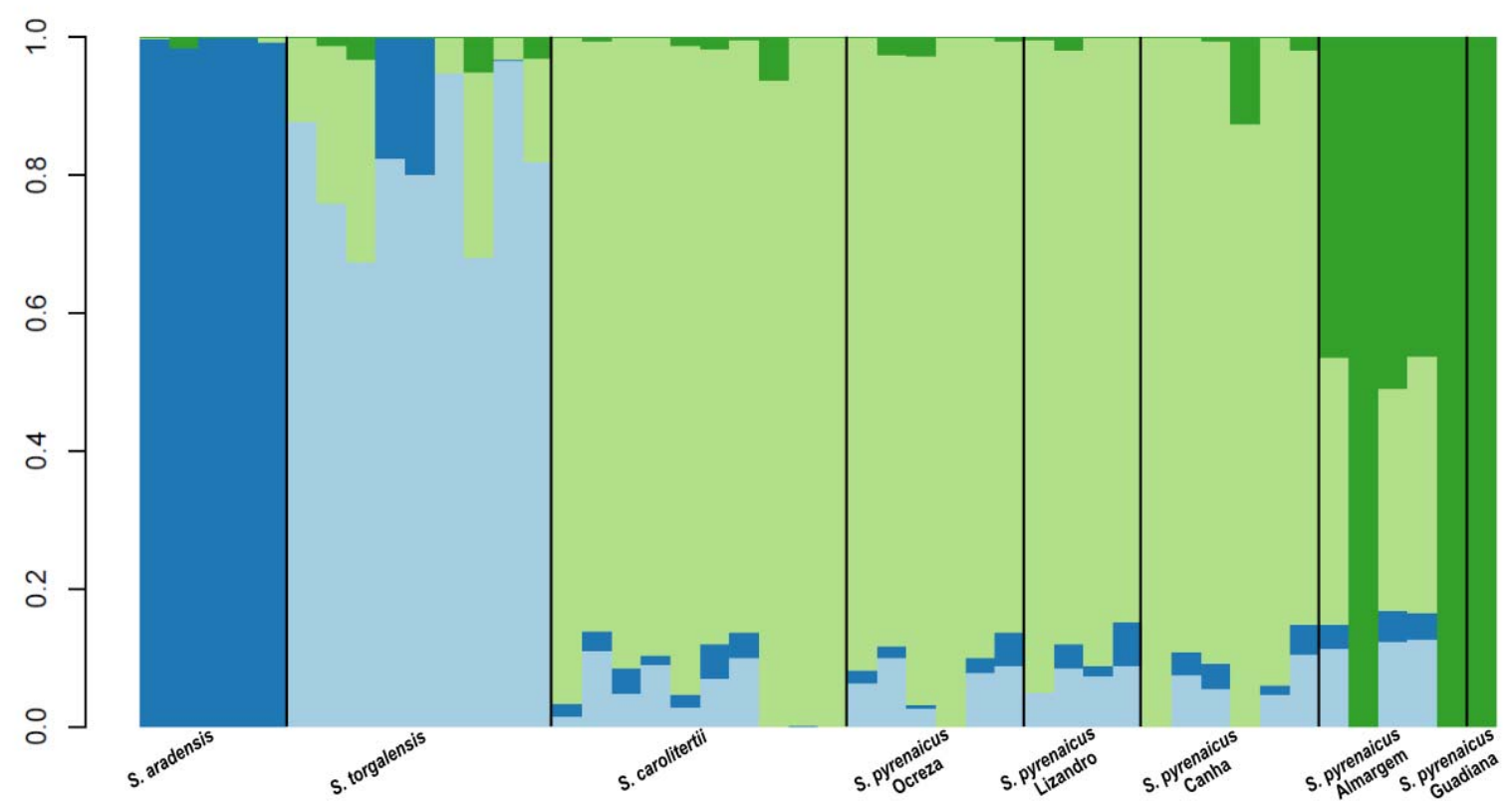

Figure 3 - Ancestry proportions inferred with sNMF for four ancestral populations $(\mathrm{K}=4)$. Each vertical bar corresponds to one individual and the proportion of each colour corresponds to the estimated ancestry proportion from a given cluster. The individuals are grouped per sampling locations separated by black lines. Ancestry proportions were inferred based on the dataset with 25,353 SNPs, filtered with MAF $\geq 0.01$ and keeping only SNPs with a depth of coverage between $1 / 4$ and 4 times the individual median depth of coverage. 
bioRxiv preprint doi: https://doi.org/10.1101/585687; this version posted July 20, 2019. The copyright holder for this preprint (which was not certified by peer review) is the author/funder, who has granted bioRxiv a license to display the preprint in perpetuity. It is made available under aCC-BY-NC-ND 4.0 International license.

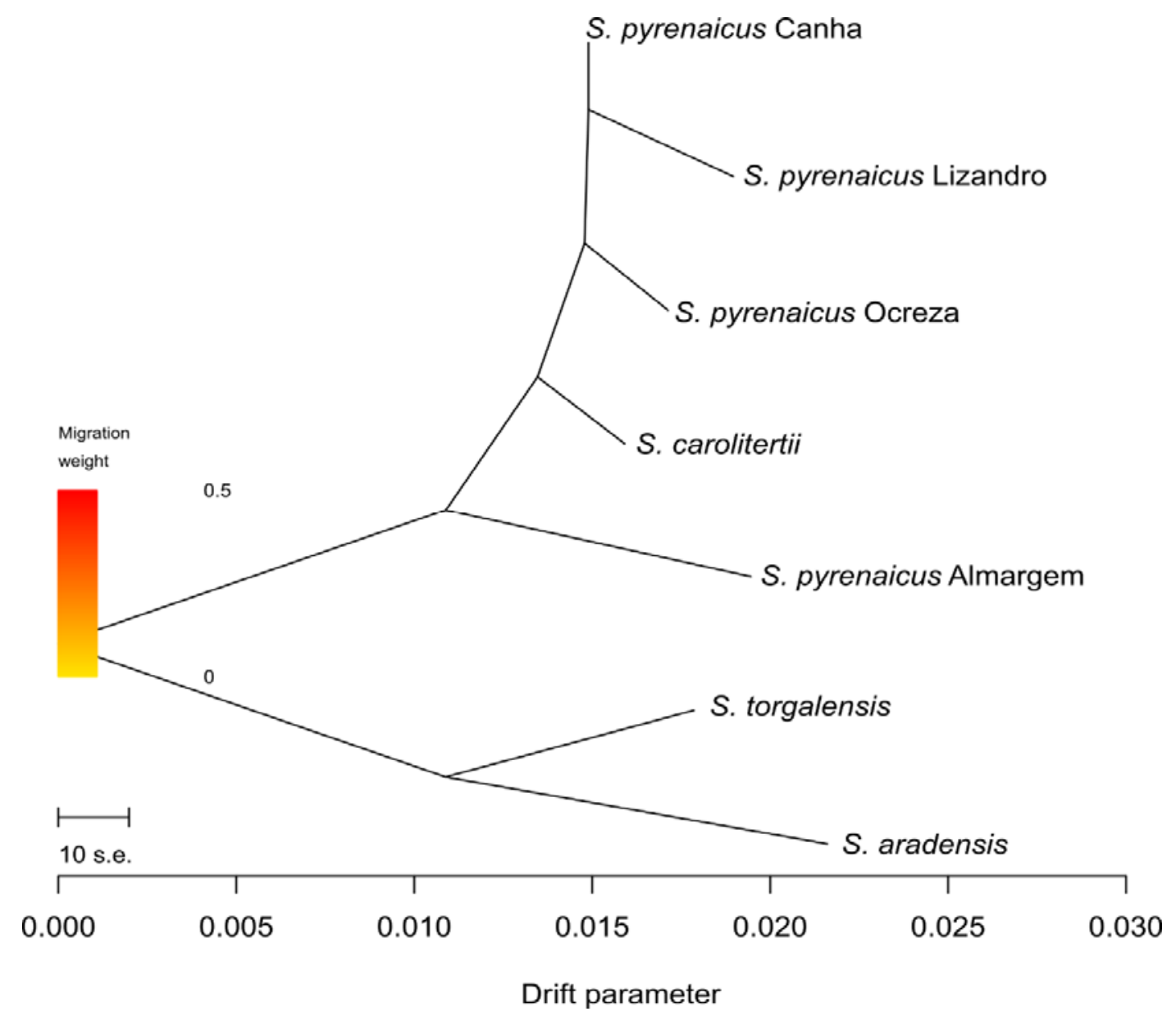

939

$940 \quad$ Figure 4 - Species tree graph obtained with TreeMix. This is an unrooted tree and branch 941 lengths are represented in units of genetic drift, i.e. the longer a given branch the stronger 942 the genetic drift experienced in that lineage, which could be due to longer divergence times 943 and/or smaller effective sizes. The species tree was inferred based on the dataset with

94425,353 SNPs, filtered with MAF $\geq 0.01$ and keeping only SNPs with a depth of coverage 945 between $1 / 4$ and 4 times the individual median depth of coverage.

946

947 
bioRxiv preprint doi: https://doi.org/10.1101/585687; this version posted July 20, 2019. The copyright holder for this preprint (which was not certified by peer review) is the author/funder, who has granted bioRxiv a license to display the preprint in perpetuity. It is made available under aCC-BY-NC-ND 4.0 International license.

(A)

D-stat (Spyr Almargem, SpyrX, Scarol, Soutg)

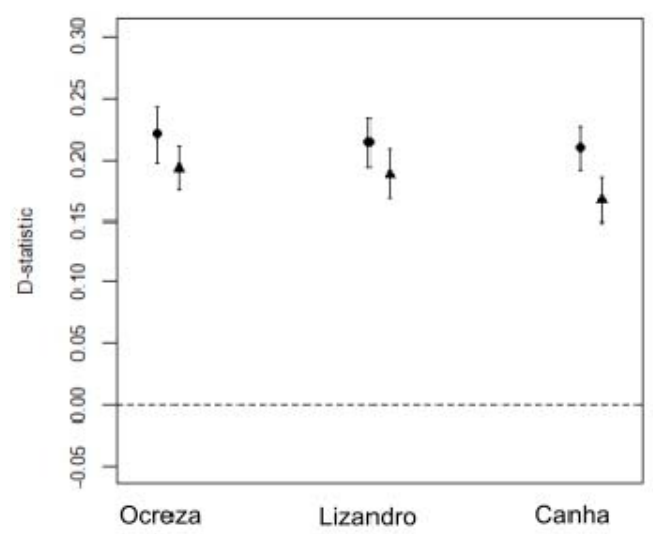

(C)

D-stat (Scarol, Spyr Ocreza, SpyrX, Soutg)

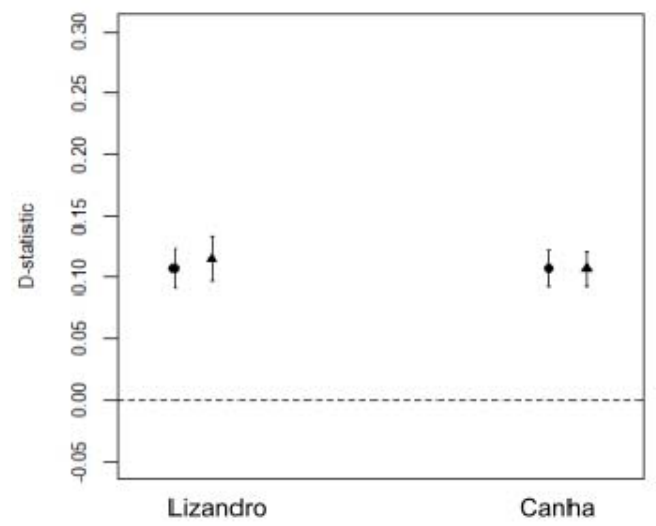

(B)

D-stat (Scarol, SpyrX, Spyr Almargem, Soutg)

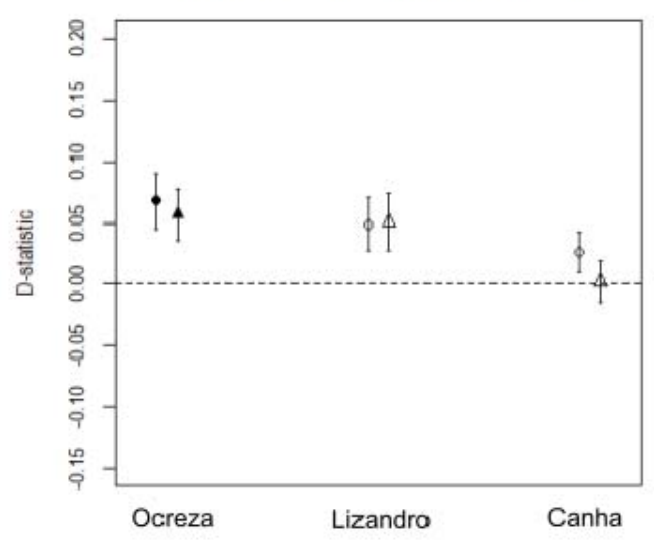

(D)

D-stat (SpyrX, Spyr Ocreza, Scarol, Soutg)

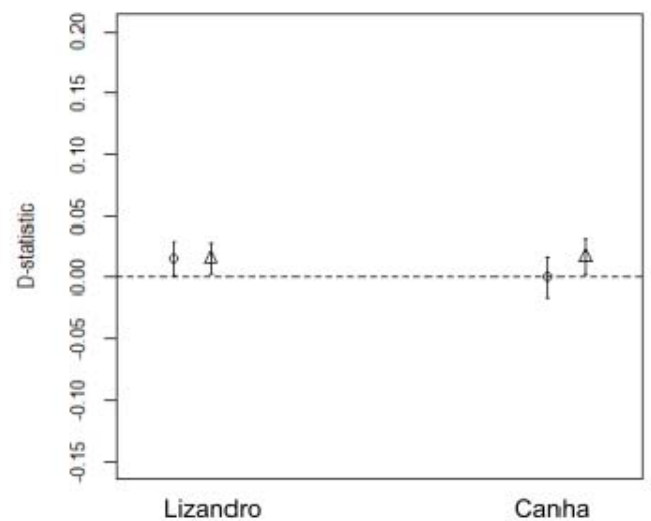

Figure 5 - Results of the D-statistic calculated for different topologies. For each topology (A to D), the results are presented according to the northern S. pyrenaicus sampling location (S. pyrX) used. "S.carol" stands for $S$. carolitertii, "S.pyr Almargem" stands for S. pyrenaicus Almargem, "S.pyr Ocreza" stands for S. pyrenaicus Ocreza and "Outg" for outgroup. Results obtained with each outgroup are represented by a different symbol (circles for $S$. aradensis and triangles for $S$. torgalensis). Full symbols represent significant $D$ values $(p<0.01)$. The $D$-statistic was calculated based on the dataset with 25,353 SNPs, filtered with MAF $\geq 0.01$ and keeping only SNPs with a depth of coverage between $1 / 4$ and 4 times the individual median depth of coverage. 
bioRxiv preprint doi: https://doi.org/10.1101/585687; this version posted July 20,2019 . The copyright holder for this preprint (which was not certified by peer review) is the author/funder, who has granted bioRxiv a license to display the preprint in perpetuity. It is made available under aCC-BY-NC-ND 4.0 International license.

950

951

952 


\section{(A)}

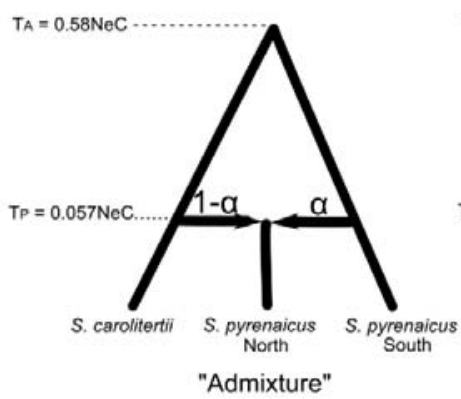

Dif. to Max. Likelihood: -177.22 $a=11.35 \%$
(B)

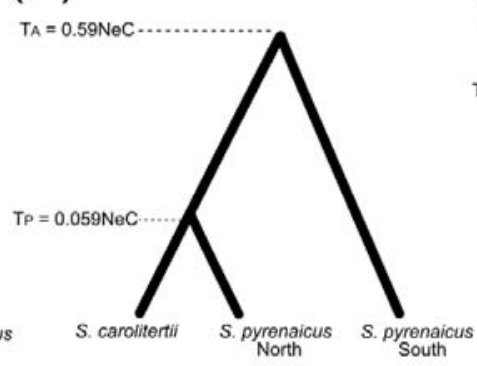

"No admixture C-PN"

Dif. to Max. Likelihood: -183.87
(C)

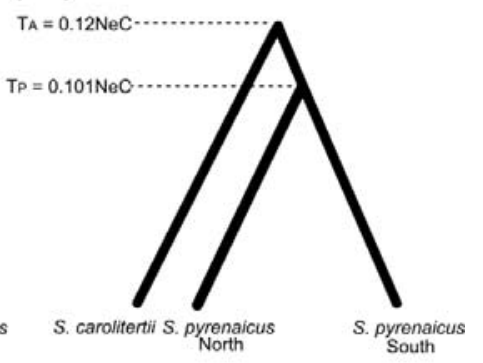

"No admixture PN-PS"

Dif. to Max. Likelihood: -296.17
(D)

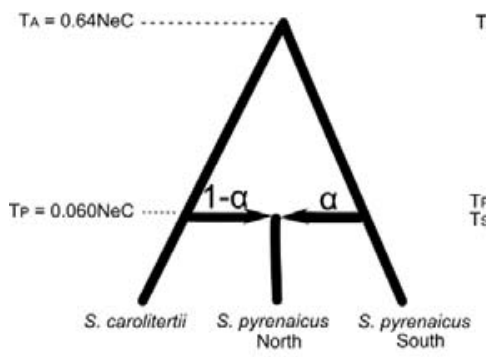

"Hybrid Origin"

Dif. to Max. Likelihood: -176.73
(E)

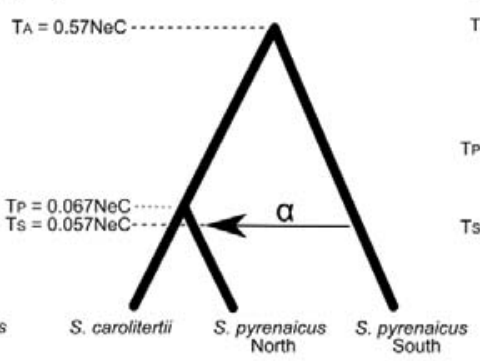

"C-PN + Sec Contact PS-PN"

Dif. to Max. Likelihood: -177.73

$$
a=8.03 \%
$$

$(\mathrm{F})$

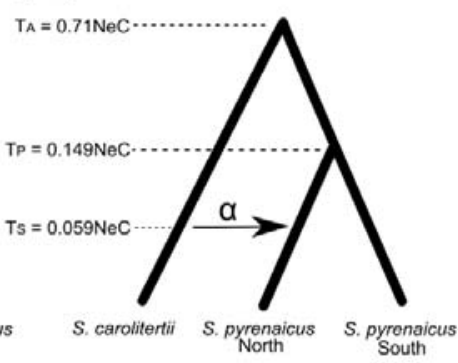

"PN-PS + Sec Contact C-PN"

Dif. to Max. Likelihood: -177.47

$$
\alpha=86.36 \%
$$

Figure 6 - Schematic representation of the likelihood of the models tested with fastsimcoal2 and percentages of admixture inferred. The name given to each model is indicated below the schematic representation, as well the difference to maximum likelihood (Dif. To Max. Likelihood) which is the difference in $\log 10$ units between the estimated likelihood and the maximum likelihood if there was a perfect fit to the observed site frequency spectrum. The closer to zero (less negative values), the better the fit. a indicates the percentage of admixture estimated. Models (A) to (C) have 8 parameters and therefore are directly comparable. Models (D) to (F) have 9 parameters and are also directly comparable. The inferred divergence times (calculated in relation to the $\mathrm{Ne}$ of $S$. carolitertii $(\mathrm{NeC}))$ are indicated on each model: $T_{A}$ - divergence from the ancestral; $T_{P}$ - divergence of the northern $S$. pyrenaicus; $T_{S}$ - secondary contact. 
bioRxiv preprint doi: https://doi.org/10.1101/585687; this version posted July 20,2019 . The copyright holder for this preprint (which was not certified by peer review) is the author/funder, who has granted bioRxiv a license to display the preprint in perpetuity. It is made available under aCC-BY-NC-ND 4.0 International license.

968 Table 1 - Pairwise $F_{S T}$ calculated between the different sampling locations. $S$.

969 pyrenaicus Guadiana was deliberately left out as there is only one individual from this

970 sampling location.

\begin{tabular}{|c|c|c|c|c|c|c|c|}
\hline & S. carolitertii & $\begin{array}{c}\text { S. pyrenaicus } \\
\text { Ocreza }\end{array}$ & $\begin{array}{l}\text { S. pyrenaicus } \\
\text { Lizandro }\end{array}$ & $\begin{array}{l}\text { S. pyrenaicus } \\
\text { Canha }\end{array}$ & $\begin{array}{l}\text { S. pyrenaicus } \\
\text { Almargem }\end{array}$ & S. torgalensis & S. aradensis \\
\hline S. carolitertii & - & 0.126 & 0.165 & 0.081 & 0.217 & 0.377 & 0.368 \\
\hline $\begin{array}{l}\text { S. pyrenaicus } \\
\text { Ocreza }\end{array}$ & - & - & 0.161 & 0.070 & 0.234 & 0.401 & 0.391 \\
\hline $\begin{array}{l}\text { S. pyrenaicus } \\
\text { Lizandro }\end{array}$ & - & - & - & 0.092 & 0.271 & 0.427 & 0.414 \\
\hline $\begin{array}{l}\text { S. pyrenaicus } \\
\text { Canha }\end{array}$ & - & - & - & - & 0.201 & 0.364 & 0.352 \\
\hline $\begin{array}{l}\text { S. pyrenaicus } \\
\text { Almargem }\end{array}$ & - & - & - & - & - & 0.400 & 0.390 \\
\hline S. torgalensis & - & - & - & - & - & - & 0.225 \\
\hline S. aradensis & - & - & - & - & - & - & - \\
\hline
\end{tabular}

971

972 